\title{
ANALISIS HUMAN ERROR DENGAN PENDEKATAN METODE SHERPA DAN HEART PADA PRODUKSI BATU BATA UKM YASIN
}

\author{
Sri Zetli* \\ Program Studi Teknik Industri, Fakultas Teknik dan Komputer, Universitas Putera Batam \\ Email: sri.zetli@puterabatam.ac.id
}

Artikel masuk : 13-10-2021

Artikel direvisi : 17-11-2021
${ }^{*}$ Penulis Korespondensi

Artikel diterima : 08-12-2021

\begin{abstract}
Abstrak -- Kesalahan kerja yang terjadi banyak diakibatkan oleh manusia itu sendiri yang disebut dengan human error. Human error yang sering terjadi dalam kegiatan produksi bisa merugikan perusahaan dalam mewujudkan efektivitas dan efisiensi produksi. Oleh karena itu maka perlu dilakukan perbaikan performansi pekerja untuk mengurangi seringnya terjadi kesalahan kerja. Beberapa metode dalam mengidentifikasi human error diantaranya metode SHERPA dan HEART. SHERPA suatu metode kualitatif dalam menganalisis human error yang menjadikan task level sebagai dasar inputnya. Sedangkan HEART adalah metode dalam menentukan resiko human error yang cepat, sederhana dan gampang dimengerti oleh para engineers dan juga human factors specialists. UKM Yasin merupakan salah satu UKM yang bergerak dalam produksi batu bata di Kota Batam. Proses pembuatan batu bata melalui beberapa tahapan yaitu proses pencetakan, proses pengeringan dan proses pembakaran. Permasalahan yang masih sering terjadi yaitu kesalahan saat melakukan pekerjaan yang berakibat terhadap kecelakaan kerja dan juga berpengaruh terhadap output produksi batu bata, hal ini disebabkan oleh human error. Hasil penelitian untuk rekomendasi yang akan diperlukan untuk mereduksi error pada proses produksi batu bata dengan metode SHERPA yaitu melakukan pemeriksaan secara teliti dan rutin terhadap masing-masing proses dan memberikan pelatihan secara berkala terhadap pekerja. Peluang terjadinya error dalam setiap aktivitas pekerjaan pada produksi batu bata dengan menggunakan metode HEART dimana nilai human error probability yang paling besar yaitu 0.16. Proses yang mungkin terjadinya human error dalam tahapan proses produksi batu bata di UKM Yasin melalui nilai Human Error Probability (HEP) tertinggi yaitu 0.544 yang terdapat pada proses pembakaran batu bata.
\end{abstract}

Kata kunci: Human Error; HEART; SHERPA

\begin{abstract}
Many work errors that occur are caused by humans themselves, called human errors. Human errors that often occur in production activities can harm the company in realizing the effectiveness and efficiency of production. It is necessary to improve workers' performance to reduce the frequent occurrence of work errors. Several methods for identifying human error include the SHERPA and HEART methods. SHERPA is a qualitative method in analyzing human error using basic level tasks as input. UKM Yasin is one of the UKM engaged in brick production in Batam City. Making bricks goes through several stages: the moulding process, drying, and combustion process. The problem that still often occurs is mistakes when doing work, which results in work accidents and affects the output of brick production, which is caused by human error. The research results for recommendations that will be needed to reduce errors in the brick production process with the SHERPA method are to carry out careful and routine inspections of each process and provide regular training to workers. The probability of error in every work activity in brick production using the HEART method where the greatest probability of human error is 0.16 . The process that may occur human error in the stages of the brick production process at UKM Yasin through the highest Human Error Probability (HEP) value is 0.544 , which is found in the brick burning process.
\end{abstract}

Keywords: Human Error; HEART; SHERPA 


\section{PENDAHULUAN}

Manusia memiliki peranan penting dalam hal apapun tidak terkecuali dalam dunia kerja. Meskipun manusia cerdas, mudah beradaptasi dan memiliki kemampuan untuk belajar dari waktu ke waktu, mereka rentan terhadap kesalahan. Pada umumnya pekerjaan yang dilakukan oleh manusia bersifat repetitif yaitu berulang-ulang. Pekerjaan yang berulang-ulang inilah salah satu yang dapat mengakibatkan terjadinya kesalahan kerja yang berdampak pada efektivitas dan performansi suatu sistem.

Kesalahan kerja yang terjadi tidak sedikit diakibatkan oleh manusia itu sendiri yang disebut dengan human error. Human error merupakan tindakan atau perilaku yang dapat mengurangi efektifitas, keamanan dan performansi suatu sistem (Sanders \& McCormick, 1993). Human error selain disebabkan oleh manusia, juga bisa terjadi karena kesalahan kesalahan dalam perancangan dan prosedur kerja. Human error yang sering terjadi dalam kegiatan produksi bisa merugikan perusahaan dalam mewujudkan efektivitas dan efisiensi produksi. Tingkat kesalahan ini perlu diminimalkan melalui perbaikan pekerja.

Ada beberapa metode dalam mengidentifikasi human error diantaranya metode SHERPA (Systematic Human Error Reduction and Prediction) dan HEART (Human Error Assessment and Reduction Technique). SHERPA adalah salah satu metode yang bersifat kualitatif untuk tujuan menganalisa human error dengan cara memakai task level untuk dasar penginputannya. SHERPA sebagai teknik identifikasi human error yang menggunakan analisis tugas hirarki dalam hubungannya dengan taksonomi kesalahan untuk mengidentifikasi kesalahan kredibel yang terkait dengan aktivitas manusia (Kirwan, 2017; Utama et al., 2020). Keuntungan SHERPA adalah teknik terstruktur dan komprehensif yang dapat dengan mudah diajarkan dan diterapkan, secara substansial lebih hemat waktu daripada metode observasi, dan menghasilkan nilai reliabilitas antar penilai yang dapat diterima (Hughes et al., 2015). Sedangkan metode HEART dipakai untuk menentukan besarnya peluang error yang terjadi di setiap aktivitas suatu pekerjaan (Rahmania et al., 2013). Implementasi metode SHERPA dan HEART mampu membantu mengidentifikasi human error pada proses produksi makanan ringan yaitu cassava chips dan dilakukan perbaikan untuk meningkatkan standar mutu (Alatas \& Putri, 2017). Identifikasi dengan metode SHERPA mendapatkan aktivitas kritis pada proses produksi pintu mexicano dan nilai total HEP operator dengan metode HEART. Hasil analisa tersebut dilakukan perbaikan dengan cara meningkatkan skill dan tingkat ketelitian operator (Sembiring et al., 2019). Metode SHERPA mampu membantu mengidentifikasi 36 kesalahan tindakan, 9 kesalahan pemilihan, 8 kesalahan pencarian informasi dan 6 kesalahan pemeriksaan pada proses operasi perakitan. Probabilitas kesalahan manusia tertinggi berdasarkan metode HEART adalah kesalahan terkait geometri. Studi tersebut menunjukkan bahwa instruksi perakitan yang jelas menawarkan potensi tertinggi untuk pengurangan kesalahan dan peningkatan kinerja (Torres et al., 2021).

UKM Yasin merupakan salah satu UKM yang bergerak dalam produksi batu bata di Kota Batam. Pada proses produksi batu bata melalui beberapa aktifitas, diantaranya prose pencetakan batu bata, proses pengeringan dan proses pembakaran. Dalam proses produksi batu bata masih banyak dilakukan secara manual seperti pengeringan dengan memanfaatkan alam yaitu panas dan udara, proses pembakaran dengan menggunakan kayu panggang, namun pada pengolahan bahan baku batu bata sudah dilakukan secara semi mekanis dengan mesin pengaduk.

Berdasarkan informasi yang didapat dari pihak pengolah batu bata, masih seringnya terjadi kesalahan pada pekerja yang sangat berpengaruh kepada keselamatan pekerjanya, selain itu juga sangat berpengaruh terhadap output produksi batu bata. Dimana dari hasil output produk batu bata, masih banyak terdapat produk cacat salah satunya yaitu batu bata yang mudah pecah. Tidak ada pembukuan ataupun catatan khusus yang dibuat oleh UKM Yasin, namun dari wawancara yang dilakukan dengan pihak UKM diperoleh data bahwa hasil produksi rata-rata tiap bulannya adalah 200.000 pcs. Produksi batu bata juga berpengaruh terhadap kondisi lingkungan, biasanya kondisi lingkungan dingin atau hujan akan memperlambat proses pengeringan sedangkan kondisi lingkungan panas akan mempercepat proses pengeringan. Rata-rata batu bata yang mengalami cacat yaitu berkisar $5.000-15.000$ pcs tiap bulannya.

Kesalahan yang masih sering terjadi yaitu seperti proses pencetakan batu bata dimana pekerja lupa mengecek ukuran potong untuk batu bata sehingga menyebabkan ukuran tidak sesuai dengan ukuran standarnya $(16 \times 8.3 \times 4.3) \mathrm{cm}$. Pada proses pengeringan, kesalahan yang sering terjadi adalah pekerja kurang sigap mengambil batu bata siap cetak dari mesin cetak ke gerobak sehingga batu bata siap cetak jatuh dan harus dicetak ulang, pekerja terburu-buru saat menyusun batu bata di tempat pengeringan sehingga batu bata yang sudah disusun berantakan dan 
terjatuh sehingga menyebabkan beberapa batu bata harus dicetak ulang dan pekerja tidak memperhatikan tempat pengeringan batu bata sehingga batu bata terkena hujan saat hujan tiba. Sedangkan pada proses pembakaran hal yang sering terjadi adalah kecelakaan-kecelakaan kecil yang mengakibatkan terbakarnya tangan dan beberapa bagian tubuh pekerja yang diakibatkan tidak adanya alat safety khusus yang dipakai oleh pekerja saat pembakaran seperti sarung tangan, sepatu safety dan baju safety.

Pada proses pembakaran ini hanya menggunakan kayu bakar dalam pembakaran. Dimana batu bata disusun rapi pada sebuah tungku. Tinggi penyusunan batu bata sesuai dengan kesukaan, hal ini tergantung jumlah batu yang dikeringkan dimana semakin banyak jumlah batu yang kering maka penyusunan tungku akan semakin tinggi. Berdasarkan survey yang dilakukan oleh peneliti, tinggi batu bata yang dibakar mencapai $5 \mathrm{~m}$ dan sudah hampir mencapai atap tempat usaha batu bata. Dan informasi yang didapatkan bahwa hal ini hampir terjadi kebakaran di tempat usaha, ditambah hampir semua material tempat usaha ini berbahan kayu, begitu juga dengan atap yang berbahan terpal berlapis daun dan seng. Kebakaran pernah dialami oleh UKM ini yaitu pada tahun 2009 dimana kebakaran tersebut menghabiskan bangunan tempat usaha walaupun tidak mengalami kerugian yang cukup besar, tetapi usaha yang dilakukan harus berhenti sementata sampai bangunan tempat usaha selesai diperbaiki lagi.

Dari data tersebut diketahui kesalahan yang terjadi berakibat terhadap kecelakaan kerja dan juga berpengaruh terhadap output produksi batu bata disebabkan oleh human error. Hal ini juga erat hubungannya dengan pekerjaan yang dilakukan masih banyak secara manual yang mengakibatkan terjadi kelelahan kerja sehingga berpengaruh terhadap kesalahan kerja (human error). Kelelahan kerja dapat menurunkan kinerja seseorang dan dapat meningkatkan kesalahan kerja (Nurmianto, 2004).

\section{METODE PENELITIAN}

Populasi dalam penelitian ini adalah 1 orang pemilik usaha dan 4 pekerja pada proses produksi batu bata. Pengambilan sampel menggunakan teknik sampling jenuh dimana jumlah sampel adalah jumlah populasi. Metode pengumpulan data dilakukan dengan cara melakukan pengamatan langsung dengan melihat alur proses produksi batu bata dan langkahlangkah melakukan pekerjaan, dimana area yang diobservasi adalah seluruh proses produksi batu bata. Langkah lain adalah melakukan wawancara langsung dengan pemilik usaha dan beberapa pekerja batu bata yaitu untuk mendapatkan data kesalahan kerja pada proses produksi batu bata.

Identifikasi human error dengan melihat hasil dari nilai HEP yang terdapat pada proses produksi batu bata berdasarkan nilai HEP yang didapatkan. Nilai HEP yang besar menunjukkan bahwa tingkat human error yang terjadi pada proses produksi batu bata tinggi. Sedangkan nilai HEP yang rendah menunjukkan bahwa tingkat human error yang terjadi pada proses produksi batu bata rendah.

Metode SHERPA menganalisis kesalahan manusia yang terdiri dari pertanyaan dan jawaban umum yang membedakan kesalahan serupa pada setiap langkah analisis tugas pekerjaan (Ghasemi et al., 2013). Tahapan proses yang dilakukan dalam mengaplikasikan metode SHERPA yaitu:

1. Menerapkan analisis task ke dalam task yang akan diidentifikasi

2. Mengidentifikasi error yang menjadi potensi terjadinya dari setiap dasar task level

3. Mengidentifikasi risiko error and task selanjutnya yang bisa mengantisipasi jika error terjadi

4. Gunakan tabel SHERPA sebagai tabulasikan error

Pada metode ini model error dilihat berdasarkan bentuk error pada SHERPA. Dimana ada 5 tipe error dalam SHERPA diantaranya tindakan (action), pengambilan (retrieval), pengecekan (checking), pemilihan (selection) dan information communication (Bin Jake, 2020).

Metode HEART merupakan teknik penilaian keandalan manusia untuk membantu mengidentifikasi risiko mengidentifikasi pengaruh utama pada kinerja manusia dan kemungkinan kesalahan, dengan cara yang sistematis dan berulang-ulang (J C Williams, 2015). HEART adalah metode faktor aditif yang relatif cepat yang mudah digunakan dan dapat diterapkan pada industri mana pun yang mengutamakan keandalan manusia (Bell \& Williams, 2018). Metode ini dimaksudkan untuk menangkap esensi dari pengaruh yang diketahui pada kinerja manusia pada saat melakukan pekerjaan (Williams \& Bell, 2015). Adapun tahapan proses yang dijalankan pada hitungan Human Error Probability (HEP) yaitu memakai metode HEART (Safitri et al., 2015):

1. Gunakan Generic Categories sebagai klasifikasi jenis pekerjaan yang ada pada tabel HEART.

Terdapat 8 kategori Generic categories dari HEART (mulai A - H) kemudian dilengkapi dengan nilai nominal human unreliability pada setiap kategori. Untuk contohnya pada kategori A nilai nominal human unreliability 
0.55. Maka jenis pekerjaan yang termasuk kategori $A$ yaitu pekerjaan yang tidak terbiasa dikerjakan dan dijalankan secara cepat tanpa mengetahui kemungkinan akibat yang terjadi.

2. Menentukan nilai Error Producing Condition (EPCs)

ECPs adalah faktor yang menjadi penyebab error. Pada kondisi dilapangan hal yang menjadi faktor penyebab error yang diklasifikasikan sesuai dengan EPCs. Faktor ini melihatkan kisaran nilai tertinggi dimana ketidakandalan akan merubah kondisi dari yang baik ke buruk. Masing-masing EPCs mempunyai nilai berpengaruh tertinggi yang memiliki nilai yang ditetapkan setelah divalidasi oleh Jeremy Williams. EPCs dan juga nilai pengaruh paling besarnya.

3. Penentuan nilai proporsi (PoA)

Nilai ini berada antara $0-1(0=$ Low, $1=$ High $)$. Nilai 0 artinya EPCs yang diukur tidak mempengaruhi terhadap kemungkinan terjadi error, berada dengan nilai 1 berpengaruh paling besar terhadap kemungkinan terjadinya error pada EPCs. Proporsi penilaiannya dilakukan oleh para ahli yang bersifat subyektif.

4. Melakukan perhitungan nilai Human Error Probability (HEP)

Rumus untuk nilai HEP pada HEART adalah:

$H E P=$ NHU $\times$ AE $1 \times$ AE $2 \times$ AE $3 \times$ AE ...n

$A E=($ PoA $\times($ Total HEART Effect -1$)+1) \mathrm{AE}$

= Assessed Effect

$\mathrm{NHU}=$ Nominal Human Unreliability

\section{HASIL DAN PEMBAHASAN \\ Prediksi Human Error dengan Metode SHERPA}

Hierarchical Task Analysis (HTA) didasarkan pada gagasan bahwa kinerja tugas dapat dinyatakan dalam hirarki tujuan, operasi dan rencana. HTA memperlihatkan task/kegiatan yang harus dikerjakan oleh pekerja dalam menghasilkan sebuah produk. Untuk alur proses produksi batu bata di UKM Yasin dapat di lihat pada Gambar 1, Gambar 2 dan Gambar 3. Pada gambar tersebut memperlihatkan task yang harus dilakukan oleh pekerja pada bagian masingmasing proses produksi batu bata. Sehingga dari HTA setiap bagian proses produksi dapat diprediksi human error yang mungkin saja terjadi saat pekerja melakukan pekerjaannya.

Human Error Identification (HEI) menentukan mode error yang ada pada tabel SHERPA dengan melihat deskripsi Error. HEl untuk masingmasing proses produksi dapat dilihat pada Tabel 1, Tabel 2 dan Tabel 3.

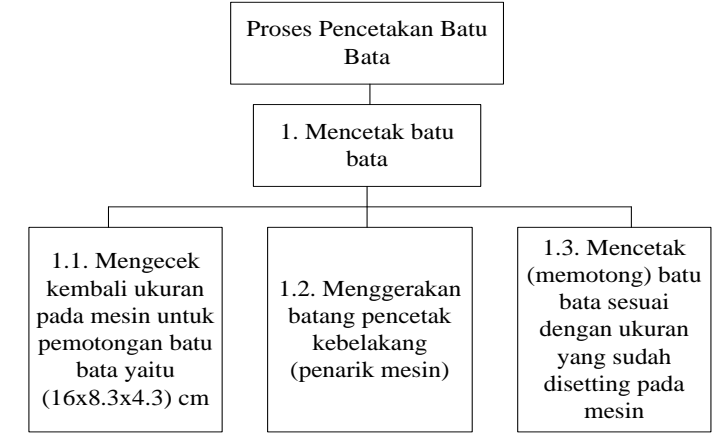

Gambar 1. HTA Proses Pencetakan Batu Bata



Gambar 2. HTA Proses Pengeringan Batu Bata

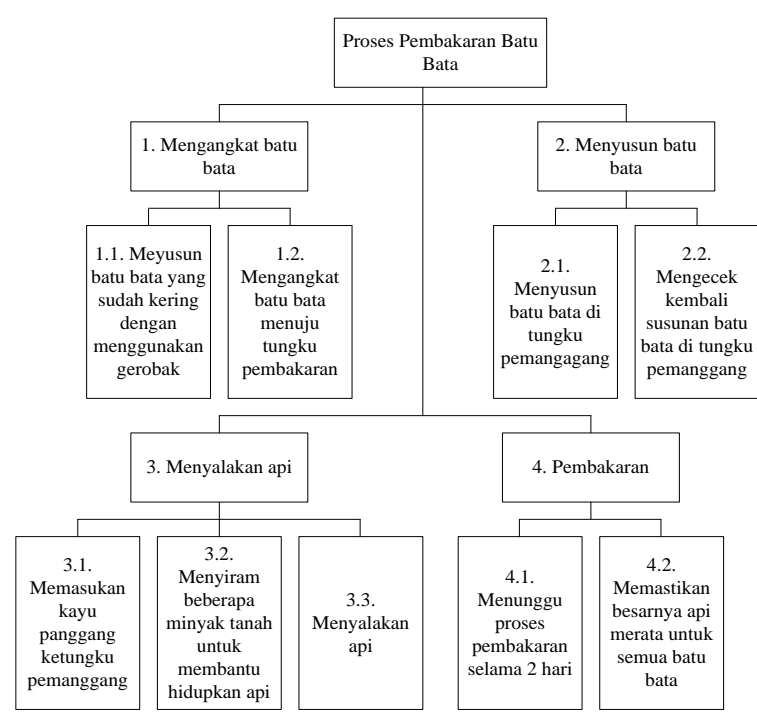

Gambar 4. HTA Proses Pembakaran Batu Bata 
Tabel 1. HEI Proses Pencetakan Batu Bata

\begin{tabular}{ccc}
$\begin{array}{c}\text { No. } \\
\text { Task }\end{array}$ & $\begin{array}{c}\text { Mode } \\
\text { Error }\end{array}$ & \multicolumn{1}{c}{ Deskripsi Error } \\
1.1 & C1 & $\begin{array}{l}\text { Pekerja tidak melakukan } \\
\text { pemeriksaan ukuran mesin } \\
\text { untuk potongan batu bata }\end{array}$ \\
1.2 & A7 & $\begin{array}{l}\text { Pekerja terlalu kencang } \\
\text { menggerakan penarik mesin } \\
\text { Batu bata tidak terpotong } \\
\text { sesuai dengan ukuran }\end{array}$ \\
\hline
\end{tabular}

Tabel 2. HEI Proses Pengeringan Batu Bata

\begin{tabular}{ccl}
\hline $\begin{array}{c}\text { No. } \\
\text { Task }\end{array}$ & $\begin{array}{c}\text { Mode } \\
\text { Error }\end{array}$ & \multicolumn{1}{c}{ Deskripsi Error } \\
\hline 1.1 & C1 & $\begin{array}{l}\text { Pekerja tidak memperhatikan } \\
\text { susunan hasil cetakan }\end{array}$ \\
1.2 & A8 & $\begin{array}{l}\text { Pekerja tidak mengangkat batu } \\
\text { bata siap cetak secara hati-hati }\end{array}$ \\
2.1 & C1 & $\begin{array}{l}\text { Pekerja tidak memperhatikan } \\
\text { susunan hasil cetakan di } \\
\text { tempat pengeringan }\end{array}$ \\
2.2 & C1 & $\begin{array}{l}\text { Pekerja tidak menyusun batu } \\
\text { bata secara terpisah }\end{array}$ \\
3.1 & A1 & $\begin{array}{l}\text { Pekerja tidak memperhatikan } \\
\text { waktu pengeringan }\end{array}$ \\
3.2 & C2 & $\begin{array}{l}\text { Pekerja tidak memperhatikan } \\
\text { susunan batu bata saat } \\
\text { pengeringan yang terkena } \\
\text { hujan secara langsung }\end{array}$ \\
\hline
\end{tabular}

Tabel 3. HEI Proses Pembakaran Batu Bata

\begin{tabular}{|c|c|c|}
\hline $\begin{array}{l}\text { No. } \\
\text { Task }\end{array}$ & $\begin{array}{l}\text { Mode } \\
\text { Error }\end{array}$ & Deskripsi Error \\
\hline 1.1 & A8 & $\begin{array}{l}\text { Pekerja menyusun batu bata } \\
\text { ke gerobak tidak hati-hati }\end{array}$ \\
\hline 1.2 & C1 & $\begin{array}{l}\text { Pekerja tidak memperhatikan } \\
\text { kapasitas berat angkat }\end{array}$ \\
\hline 2.1 & A8 & $\begin{array}{l}\text { Pekerja menyusun batu bata di } \\
\text { tungku melebihi kapasitas } \\
\text { tungku }\end{array}$ \\
\hline 2.2 & C1 & $\begin{array}{l}\text { Pekerja tidak mengecek } \\
\text { secara teliti susunan batu bata } \\
\text { Pekerja tidak memperhatikan }\end{array}$ \\
\hline 3.1 & A8 & $\begin{array}{l}\text { banyaknya kayu panggang } \\
\text { yang disusun di tungku } \\
\text { Pekeria terlalu }\end{array}$ \\
\hline 3.2 & A8 & $\begin{array}{l}\text { sedikit/kebanyakan } \\
\text { kebanyakan menyiram minyak } \\
\text { tanah untuk memancing api }\end{array}$ \\
\hline 3.3 & C1 & $\begin{array}{l}\text { Pekerja tidak menyalakan api } \\
\text { dengan hati-hati }\end{array}$ \\
\hline 4.1 & A1 & $\begin{array}{l}\text { Pekerja tidak memperhatikan } \\
\text { waktu pembakaran }\end{array}$ \\
\hline 4.2 & C1 & $\begin{array}{l}\text { Pekerja tidak memperhatikan } \\
\text { api pemanggangan }\end{array}$ \\
\hline
\end{tabular}

Tabel 1 menjelaskan deskripsi human error yang mungkin terjadi pada saat pekerja melakukan pekerjaannya pada proses pencetakan batu bata. Berdasarkan kesalahan kerja yang pernah terjadi di UKM Yasin, kelalaian pekerja merupakan salah satu penyebab terjadinya salah dalam ukuran batu bata sehingga tidak sesuai dengan standar ukuran batu bata yaitu $(16 \times 8.3 \times 4.3) \mathrm{cm}$. HEl untuk kelalaian pekerja yaitu pekerja lupa mengecek ukuran potong untuk batu bata sehingga menyebabkan ukuran tidak sesuai dengan ukuran standarnya.

Tabel 2 menjelaskan deskripsi human error yang mungkin terjadi pada saat pekerja melakukan pekerjaannya pada proses pengeringan batu bata. Berdasarkan kesalahan kerja yang pernah terjadi di UKM Yasin, kelalaian pekerja merupakan salah satu penyebab terjadinya pekerjaan ulang dan lama dalam proses pengeringan. $\mathrm{HEI}$ untuk kelalaian pekerja yaitu pekerja kurang sigap mengambil batu bata siap cetak dari mesin cetak ke gerobak sehingga batu bata siap cetak jatuh dan juga terburu-buru saat menyusun batu bata di tempat pengeringan sehingga batu bata yang sudah disusun berantakan dan terjatuh sehingga menyebabkan beberapa batu bata harus dicetak ulang. Selain itu pekerja tidak memperhatikan tempat pengeringan batu bata sehingga batu bata terkena hujan saat hujan tiba dan menyebabkan proses pengeringan menjadi semakin lama.

Tabel 3 menjelaskan deskripsi human error yang mungkin terjadi pada saat pekerja melakukan pekerjaannya pada proses pembakaran batu bata. Berdasarkan kesalahan kerja yang pernah terjadi di UKM Yasin, kelalaian pekerja merupakan salah satu penyebab terjadinya bata tidak terbakar sempurna dan juga menyebabkan kecelakaan kerja. HEI untuk kelalaian pekerja yaitu pekerja tidak memperhatikan kapasitas tungku sehingga pekerja menyusun batu bata melebihi kapasitas hal ini pernah menyebabkan kebakaran karena batu bata yang disusun sudah hampir mengenai atap gubuk batu bata. Selain itu juga pekerja tidak memperhatikan besarnya api sehingga api tidak merata ke semua batu bata dan menyebabkan beberapa batu bata tidak terbakar sempurna.

Konsekuensi analisis yaitu mengidentifikasi terhadap konsekuensi error dan task yang berikutnya sehingga bisa mengantisipasi jika terjadi error. Tabel 4 menjelaskan akibat human error yang mungkin terjadi saat pekerja melakukan pekerjaannya pada proses pencetakan batu bata. Konsekuensinya yaitu pekerjaan berulang dan ukuran batu bata tidak sesuai standar. 
Tabel 5 menjelaskan akibat human error yang mungkin terjadi saat pekerja melakukan pekerjaannya pada proses pengeringan batu bata. Konsekuensinya yaitu pekerjaan menjadi lama, pekerjaan berulang dan kualitas batu bata tidak bagus.

Tabel 6 menjelaskan akibat human error yang mungkin terjadi saat pekerja melakukan pekerjaannya pada proses pembakaran batu bata. Konsekuensinya yaitu menimbulkan kecelakaan kerja yaitu tempat usaha terbakar, pekerja terkena apai, batu bata tidak terbakar sempurna dan kualitas batu bata tidak bagus sehingga mudah pecah.

Tabel 4. Konsekuensi Analisis Proses Pencetakan Batu Bata

\begin{tabular}{cl}
\hline $\begin{array}{c}\text { No. } \\
\text { Task }\end{array}$ & \multicolumn{1}{c}{ Konsekuensi } \\
\hline 1.1 & Ukuran batu bata tidak sesuai \\
1.2 & Standar \\
1.3 & $\begin{array}{l}\text { Ukekerjaan menjadi berulang batu bata tidak sesuai } \\
\text { standar }\end{array}$ \\
\hline
\end{tabular}

Tabel 5. Konsekuensi Analisis Proses Pengeringan Batu Bata

\begin{tabular}{cl}
\hline $\begin{array}{c}\text { No. } \\
\text { Task }\end{array}$ & \multicolumn{1}{c}{ Konsekuensi } \\
\hline 1.1 & Pekerjaan menjadi lama \\
1.2 & $\begin{array}{l}\text { Batu bata jatuh dan harus dicetak } \\
\text { ulang }\end{array}$ \\
2.1 & Batu bata jatuh dan harus dicetak \\
2.2 & Plang \\
3.1 & Batu bata tidak terlalu kering dan \\
3.2 & Pualitas tidak bagus \\
\hline
\end{tabular}

Tabel 6. Konsekuensi Analisis Proses Pembakaran Batu Bata

\begin{tabular}{|c|c|}
\hline $\begin{array}{l}\text { No. } \\
\text { Task }\end{array}$ & Konsekuensi \\
\hline 1.1 & Batu bata jatuh dan pecah \\
\hline 1.2 & $\begin{array}{l}\text { Pekerja cepat lelah dan menimbulkan } \\
\text { kecelakaan kerja }\end{array}$ \\
\hline 2.1 & $\begin{array}{l}\text { Susunan batu bata menjulang tinggi } \\
\text { sampai ke atap gubuk dan saat } \\
\text { pembakaran gubuk ikut terbakar }\end{array}$ \\
\hline 2.2 & Batu bata tidak terbakar sempurna \\
\hline 3.1 & Waktu pembakaran menjadi lama \\
\hline 3.2 & $\begin{array}{l}\text { Terlalu sedikit menyebabkan waktu } \\
\text { menghidupkan api menjadi lama }\end{array}$ \\
\hline 3.3 & Pekerja terkena api \\
\hline 4.1 & Batu bata tidak terbakar sempurna \\
\hline 4.2 & Kualitas batu bata tidak bagus \\
\hline
\end{tabular}

Analisis ordinal probabilitas human error dilakukan dengan cara mengelompokan human error yang terjadi pada setiap proses produksi batu bata. High merupakan probabilitas yang mempunyai kemungkinan error tertinggi. Sedangkan low merupakan probabilitas yang memiliki potensi error paling kecil.

Tabel 7. Probabilitas Proses Pencetakan Batu Bata

\begin{tabular}{cc}
\hline No. Task & Probabilitas \\
\hline 1.1 & Low \\
1.2 & Low \\
1.3 & Low \\
\hline
\end{tabular}

Tabel 8. Probabilitas Proses Pengeringan Batu Bata

\begin{tabular}{cc}
\hline No. Task & Probabilitas \\
\hline 1.1 & Low \\
1.2 & Low \\
2.1 & Low \\
2.2 & Low \\
3.1 & Low \\
3.2 & Low \\
\hline
\end{tabular}

Tabel 9. Probabilitas Proses Pembakaran Batu Bata

\begin{tabular}{cc}
\hline No. Task & Probabilitas \\
\hline 1.1 & Low \\
1.2 & High \\
2.1 & High \\
2.2 & Low \\
3.1 & Low \\
3.2 & Low \\
3.3 & Low \\
4.1 & Low \\
4.2 & Low \\
\hline
\end{tabular}

Tabel 7 menjelaskan probabilitas human error yang mungkin terjadi saat melakukan pekerjaannya pada pekerja bagian proses pencetakan batu bata. Hasilnya terlihat bahwa semua task memiliki probabilitas low hal ini dikarenakan kesalahan kerja yang terjadi selama ini hanya sedikit dan bahkan tidak pernah terjadi.

Tabel 8 menjelaskan probabilitas human error yang mungkin terjadi saat melakukan pekerjaannya pada pekerja bagian proses pengeringan batu bata. Hasilnya terlihat bahwa semua task memiliki probabilitas low hal ini dikarenakan kesalahan kerja yang terjadi selama ini hanya sedikit dan bahkan ada beberapa kesalahan pada task tidak pernah terjadi.

Tabel 9 menjelaskan probabilitas human error yang mungkin terjadi saat melakukan pekerjaannya pada pekerja bagian proses 
pembakaran batu bata. Hasilnya terlihat bahwa 2 task memiliki probabilitas high yaitu task 1.2 dan task 2.1, hal ini dikarenakan kesalahan kerja yang terjadi berulang kali. Sedangkan task lainnya memiliki probabilitas low hal ini dikarenakan kesalahan kerja yang terjadi selama ini hanya sedikit dan bahkan ada beberapa kesalahan pada task tidak pernah terjadi.

Solusi pada perbaikan dalam proses produksi batu bata bertujuan untuk menghindari human error dan juga terjadi kecelakaan kerja.

Tabel 10. Analisis Strategi Proses Pencetakan Batu Bata

\begin{tabular}{cl}
\hline $\begin{array}{c}\text { No. } \\
\text { Task }\end{array}$ & \multicolumn{1}{c}{ Solusi Untuk Perbaikan } \\
\hline 1.1 & Melakukan pengecekan secara berkala \\
1.2 & Melakukan pelatihan secara berkala \\
1.3 & Melakukan pelatihan secara berkala \\
\hline
\end{tabular}

Tabel 11. Analisis Strategi Proses Pengeringan Batu Bata

\begin{tabular}{cl}
\hline $\begin{array}{c}\text { No. } \\
\text { Task }\end{array}$ & \multicolumn{1}{c}{ Solusi Untuk Perbaikan } \\
\hline 1.1 & Memberikan pelatihan secara berkala \\
1.2 & Memberikan pelatihan secara berkala \\
2.1 & Melakukan pengecekan secara rutin \\
2.2 & Menentukan tempat yang tepat \\
3.1 & Melakukan pemeriksaan secara rutin \\
3.2 & Menentukan tempat yang tepat \\
\hline
\end{tabular}

Tabel 12. Analisis Strategi Proses Pembakaran Batu Bata

\begin{tabular}{cl}
\hline $\begin{array}{c}\text { No. } \\
\text { Task }\end{array}$ & \multicolumn{1}{c}{ Solusi Untuk Perbaikan } \\
\hline 1.1 & Memberikan pelatihan secara berkala \\
1.2 & Menentukan berat yang sesuai untuk \\
2.1 & Membuat standar kapasitas \\
2.2 & Melakukan pengecekan secara teliti \\
3.1 & Melakukan pengecekan secara berkala \\
3.2 & Membuat standar kapasitas \\
3.3 & Melakukan pengecekan secara berkala \\
4.1 & Melakukan pengecekan secara berkala \\
4.2 & Melakukan pengecekan secara berkala \\
\hline
\end{tabular}

Tabel 10 menjelaskan probabilitas human error yang mungkin terjadi saat melakukan pekerjaannya pada pekerja bagian proses pencetakan batu bata. Hasilnya terlihat bahwa semua task memiliki probabilitas low hal ini dikarenakan kesalahan kerja yang terjadi selama ini hanya sedikit dan bahkan tidak pernah terjadi.

Tabel 11 menjelaskan probabilitas human error yang mungkin terjadi saat melakukan pekerjaannya pada pekerja bagian proses pengeringan batu bata. Hasilnya terlihat bahwa semua task memiliki probabilitas low hal ini dikarenakan kesalahan kerja yang terjadi selama ini hanya sedikit dan bahkan ada beberapa kesalahan pada task tidak pernah terjadi.

Tabel 12 menjelaskan probabilitas human error yang mungkin terjadi saat melakukan pekerjaannya pada pekerja bagian proses pembakaran batu bata. Hasilnya terlihat bahwa 2 task memiliki probabilitas high yaitu task 1.2 dan task 2.1, hal ini dikarenakan kesalahan kerja yang terjadi berulang kali. Sedangkan task lainnya memiliki probabilitas low hal ini dikarenakan kesalahan kerja yang terjadi selama ini hanya sedikit dan bahkan ada beberapa kesalahan pada task tidak pernah terjadi.

\section{Probabilitas Terjadinya Human Error dengan Metode HEART}

Pada tahapan ini dilakukannya klasifikasi jenis kegiatan dengan menggunakan tabel Generic Task Type (GTT). Klasifikasi tersebut dilakukan dengan melihat seperti apa jenis dari pekerjaan dilakukan oleh pekerja. Tabel 13, Tabel 14 dan Tabel 15 merupakan tabel yang mengkategorikan jenis pekerjaan dan nilai dari human error probability untuk masing-masing proses produksi batu bata.

Pada Tabel 13 terlihat kategori jenis pekerjaan dan nilai dari human error probability pada proses pencetakan batu bata. Semua task memiliki nominal human error probability sebesar 0.16 . Hal ini disebabkan pekerja membutuhkan keterampilan dan tingkat pemahaman mengenai ukuran batu bata yang sesuai standar.

Pada Tabel 14 terlihat kriteria dari jenis pekerjaan dan nilai dari human error probability untuk proses pengeringan batu bata. Nilai human error probability yang terbesar yaitu 0.16 pada task 3.1. Hal ini disebabkan pekerja membutuhkan keterampilan dan tingkat pemahaman tentang mesin, begitu juga dengan perlunya keterampilan dan pemahaman mengenai waktu pengeringan supaya batu bata kering secara sempurna sebelum di bakar.

Tabel 15 menunjukan kategori dari jenis pekerjaan dan nilai dari human error probability untuk proses pembakaran batu bata. Nilai human error probability paling besar yaitu 0.16 pada task 2.1, 2.2, 4.1, dan 4.2. Hal ini disebabkan pekerja membutuhkan keterampilan dan tingkat pemahaman tentang banyaknya kapasitas pembakaran supaya tidak terjadi kecelakaan kerja, begitu juga pekerja juga mesti memiliki keterampilan dan pemahaman mengenai pemerataan api ke setiap batu bata supaya semua batu bata terbakar sempurna. 
Tabel 13. Kategori Pekerjaan Proses Pencetakan Batu Bata

\begin{tabular}{ccc}
\hline $\begin{array}{c}\text { No. } \\
\text { Task }\end{array}$ & $\begin{array}{c}\text { Generic Task } \\
\text { Type (GTT) }\end{array}$ & $\begin{array}{c}\text { Nominal Error } \\
\text { Probability }\end{array}$ \\
\hline 1.1 & C & 0.16 \\
1.2 & C & 0.16 \\
1.3 & C & 0.16 \\
\hline
\end{tabular}

Tabel 14. Kategori Pekerjaan Proses Pengeringan Batu Bata

\begin{tabular}{ccc}
\hline $\begin{array}{c}\text { No. } \\
\text { Task }\end{array}$ & $\begin{array}{c}\text { Generic Task } \\
\text { Type (GTT) }\end{array}$ & $\begin{array}{c}\text { Nominal Error } \\
\text { Probability }\end{array}$ \\
\hline 1.1 & E & 0.02 \\
1.2 & E & 0.02 \\
2.1 & E & 0.02 \\
2.2 & E & 0.02 \\
3.1 & C & 0.16 \\
3.2 & G & 0.0004 \\
\hline
\end{tabular}

Tabel 15. Kategori Pekerjaan Proses Pembakaran Batu Bata

\begin{tabular}{ccc}
$\begin{array}{c}\text { No. } \\
\text { Task }\end{array}$ & $\begin{array}{c}\text { Generic Task } \\
\text { Type (GTT) }\end{array}$ & $\begin{array}{c}\text { Nominal Error } \\
\text { Probability }\end{array}$ \\
\hline 1.1 & G & 0.0004 \\
1.2 & E & 0.02 \\
2.1 & C & 0.16 \\
2.2 & C & 0.16 \\
3.1 & E & 0.02 \\
3.2 & G & 0.0004 \\
3.3 & E & 0.02 \\
4.1 & C & 0.16 \\
4.2 & C & 0.16 \\
\hline
\end{tabular}

Nilai Error Producing Conditions (EPC) dilihat berdasarkan faktor-faktor yang menjadi penentu pemicu terjadinya beberapa kesalahan/error terjadi pada pekerjaan. Sedangkan nilai Proportion of Effect (POE) didapat dari hasil wawancara dengan orang yang dianggap paham/ahli dalam proses pembuatan batu bata. Peneliti melakukan wawancara dengan Bapak Yasin yaitu pemilik dari UKM Batu Bata Yasin. Proportion ff Effect (POE) ini mempunyai skala 01, semakin tinggi nilai dari sebuah error, menyebabkan semakin tinggi nilai Human Error Probability (HEP) yang berarti akan semakin tinggi kemungkinan terjadinya error.

Nilai nilai Error Producing Condition (EPC) dan juga nilai Proportion of Effect (POE) menunjukan nilai Assessed Proportion of Effect (APOE). Dimana nilia Assessed Proportion of Effect (APOE) ini merupakan nilai yang memberikan gambaran besarnya kemungkinan terjadi sebuah kesalahan, semakin tinggi nilai APOE maka akan beriring dengan tingginya nilai HEP (Human Error Probability) dimana berarti semakin gampang probabilitas dari kesalahan yang terjadi.

Tabel 16, Tabel 17 dan Tabel 18 sebagian besar mendapatkan nilai EPC pada nomor 11, dimana nomor 11 yang berarti kesalahan tersebut dipengaruhi oleh ambiguitas dari standar performansi, jadi standar yang ditetapkan perusahaan tidak dimengerti dengan pasti oleh pekerja sehingga masalah tersebut yang menjadi sumber utama yaitu tidak jelas Standar Operasional Prosedur (SOP) yang berlaku. Nilai EPC terdapat pada nomor 16 dengan nilai 3 , ini berarti prosedur yang ada tidak memberikan informasi yang lengkap. Dan juga ada nilai EPC pada nomor 26, dengan nilai sebesar 1.4 bahwa dalam melakukan aktivitas tidak ada cara yang jelas pada langkah tertentu.

Tabel 16. Nilai APOE dan AE untuk Proses Pencetakan Batu Bata

\begin{tabular}{ccccc}
\hline $\begin{array}{c}\text { No. Nomor Urut } \\
\text { Task(Tabel EPCs) }\end{array}$ & $\begin{array}{c}\text { Max. } \\
\text { Effect }\end{array}$ & APOE & $\begin{array}{c}\text { AE }((\text { Max. } \\
\text { Effect }-1) \mathbf{~ x} \\
\text { APOE })+\mathbf{1}\end{array}$ \\
\hline 1.1 & 11 & 5 & 0.4 & 2.6 \\
1.2 & 11 & 5 & 0.2 & 1.8 \\
1.3 & 11 & 5 & 0.2 & 1.8 \\
\hline
\end{tabular}

Tabel 17. Nilai APOE dan AE untuk Proses Pengeringan Batu Bata

\begin{tabular}{ccccc}
\hline $\begin{array}{c}\text { No. } \\
\text { Task }\end{array}$ & $\begin{array}{c}\text { Nomor Urut } \\
\text { (Tabel } \\
\text { EPCs) }\end{array}$ & $\begin{array}{c}\text { Max. } \\
\text { Effect }\end{array}$ & APOE & $\begin{array}{c}\text { AE }((\text { Max. } \\
\text { Effect - 1) } \\
\text { x APOE) + } \\
\mathbf{1}\end{array}$ \\
\hline 1.1 & 26 & 1.4 & 0.3 & 1.12 \\
1.2 & 26 & 1.4 & 0.8 & 1.32 \\
2.1 & 11 & 5 & 0.3 & 2.2 \\
2.2 & 11 & 5 & 0.2 & 1.8 \\
3.1 & 11 & 5 & 0.4 & 2.6 \\
3.2 & 26 & 1.4 & 0.6 & 1.24 \\
\hline
\end{tabular}

Tabel 18. Nilai APOE dan AE untuk Proses Pembakaran Batu Bata

\begin{tabular}{ccccc}
\hline $\begin{array}{c}\text { No. } \\
\text { Task }\end{array}$ & $\begin{array}{c}\text { Nomor Urut } \\
\text { (Tabel } \\
\text { EPCs) }\end{array}$ & $\begin{array}{c}\text { Max. } \\
\text { Effect }\end{array}$ & APOE $\begin{array}{c}\text { AE }((\text { Max. } \\
\text { Effect }-\mathbf{1}) \mathbf{x} \\
\text { APOE })+\mathbf{1}\end{array}$ \\
\hline 1.1 & 26 & 1.4 & 0.7 & 1.28 \\
1.2 & 16 & 3 & 0.8 & 2.6 \\
2.1 & 11 & 5 & 0.6 & 3.4 \\
2.2 & 11 & 5 & 0.3 & 2.2 \\
3.1 & 26 & 1.4 & 0.2 & 1.08 \\
3.2 & 26 & 1.4 & 0.2 & 1.08 \\
3.3 & 26 & 1.4 & 0.2 & 1.08 \\
4.1 & 11 & 5 & 0.2 & 1.8 \\
4.2 & 11 & 5 & 0.2 & 1.8 \\
\hline
\end{tabular}

Dalam menghitung nilai Human Error Probability (HEP) dapat mengetahui seberapa 
besar peluang yang akan terjadi terhadap kegagalan ketika pekerja melakukan pekerjaannya. Nilai HEP ini didapatkan dari tabel GTT dan nilai APOE.

Tabel 19. Nilai HEP untuk Proses Pencetakan Batu Bata

\begin{tabular}{cccc}
\hline $\begin{array}{c}\text { No. } \\
\text { Task }\end{array}$ & $\begin{array}{c}\text { Nominal } \\
\text { Error } \\
\text { Probability }\end{array}$ & $\begin{array}{c}\text { Assessed } \\
\text { Proportion } \\
\text { of Effect } \\
\text { (APOE) }\end{array}$ & $\begin{array}{c}\text { Human } \\
\text { Error } \\
\text { Probability } \\
\text { (HEP) }\end{array}$ \\
\hline 1.1 & 0.16 & 2.6 & 0.416 \\
1.2 & 0.16 & 1.8 & 0.288 \\
1.3 & 0.16 & 1.8 & 0.288 \\
\hline
\end{tabular}

Tabel 20. Nilai HEP untuk Proses Pengeringan Batu Bata

\begin{tabular}{cccc}
\hline $\begin{array}{c}\text { No. } \\
\text { Task }\end{array}$ & $\begin{array}{c}\text { Nominal } \\
\text { Error } \\
\text { Probability }\end{array}$ & $\begin{array}{c}\text { Assessed } \\
\text { Proportion } \\
\text { of Effect } \\
\text { (APOE) }\end{array}$ & $\begin{array}{c}\text { Human } \\
\text { Error } \\
\text { Probability } \\
\text { (HEP) }\end{array}$ \\
\hline 1.1 & 0.02 & 1.12 & 0.0224 \\
1.2 & 0.02 & 1.32 & 0.0264 \\
2.1 & 0.02 & 2.2 & 0.044 \\
2.2 & 0.02 & 1.8 & 0.036 \\
3.1 & 0.16 & 2.6 & 0.416 \\
3.2 & 0.0004 & 1.24 & 0.000496 \\
\hline
\end{tabular}

Tabel 21. Nilai HEP untuk Proses Pembakaran Batu Bata

\begin{tabular}{cccc}
\hline $\begin{array}{c}\text { No. } \\
\text { Task }\end{array}$ & $\begin{array}{c}\text { Nominal } \\
\text { Error } \\
\text { Probability }\end{array}$ & $\begin{array}{c}\text { Assessed } \\
\text { Proportion } \\
\text { of Effect } \\
\text { (APOE) }\end{array}$ & $\begin{array}{c}\text { Human } \\
\text { Error } \\
\text { Probability } \\
\text { (HEP) }\end{array}$ \\
\hline 1.1 & 0.0004 & 1.28 & 0.000512 \\
1.2 & 0.02 & 2.6 & 0.052 \\
2.1 & 0.16 & 3.4 & 0.544 \\
2.2 & 0.16 & 2.2 & 0.352 \\
3.1 & 0.02 & 1.08 & 0.0216 \\
3.2 & 0.0004 & 1.08 & 0.000432 \\
3.3 & 0.02 & 1.08 & 0.0216 \\
4.1 & 0.16 & 1.8 & 0.288 \\
4.2 & 0.16 & 1.8 & 0.288 \\
\hline
\end{tabular}

Tabel 19 memperlihatkan untuk nilai HEP tertinggi untuk proses Pencetakan batu bata berada pada task 1.1 dengan nilai 0.416 yaitu pekerja tidak memeriksa ukuran pada mesin untuk pemotongan batu bata sehingga akan berakibat terhadap ukuran batu bata tidak sesuai standar.

Tabel 20 memperlihatkan untuk nilai HEP tertinggi untuk proses pengeringan batu bata berada pada task 3.1 dengan nilai 0.416 yaitu pekerja tidak memperhatikan waktu pengeringan sehingga akan mengakibatkan tidak sempurna pengeringan pada batu bata. Tabel 21 memperlihatkan untuk nilai HEP tertinggi untuk proses pembakaran batu bata berada pada task 2.1 dengan nilai 0.544 yaitu pekerja menyusun batu bata di tungku pemanggangan melebihi standar. Hal ini jika tidak diperhatikan bisa beresiko besar yaitu bisa membuat tempat usaha ikut terbakar karena tempat usaha pada dasarnya semua berbahan kayu dan terpal.

\section{KESIMPULAN}

Rekomendasi yang akan diperlukan untuk mereduksi error pada masing-masing proses produksi batu bata dengan menggunakan metode SHERPA pada proses pencetakan, pengeringan dan pembakaran batu adalah melakukan pemeriksaan secara rutin dan memberikan pelatihan secara berkala terutama kepada pekerja baru, menentukan tempat yang tepat untuk pengeringan agar terhindar dari hujan secara langsung dan membuat standar kapasitas jumlah bata yang bisa dibakar secara maksimal. Peluang terjadinya error dalam setiap aktivitas pekerjaan pada produksi batu bata dengan menggunakan metode HEART yaitu; Untuk proses pencetakan batu bata semua task memiliki nilai human error probability yaitu 0.16 . Untuk proses pengeringan batu bata nilai human error probability yang terbesar yaitu 0.16 pada task 3.1 (pekerja tidak memperhatikan waktu pengeringan). Pada proses pembakaran batu bata nilai human error probability yang terbesar yaitu 0.16 pada task 2.1 (pekerja menyusun batu bata di tungku melebihi kapasitas berat tungku), task 2.2 (pekerja tidak mengecek secara teliti susunan batu bata), task 4.1 (pekerja tidak memperhatikan waktu pembakaran), dan task 4.2 (pekerja tidak memperhatikan api pemanggangan). Penelitian selanjutnya dapat mengeksplorasi faktor-faktor organisasi dan individu dengan menggunakan pendekatan yang berbeda sebagai pelengkap Human Reliability Analysis (HRA).

\section{DAFTAR PUSTAKA}

Alatas, A. H., \& Putri, R. J. K. (2017). Identifikasi Human Eror Pada Proses Produksi Cassava Chips Dengan Menggunakan Metode Sherpa Dan Heart Di PT. Indofood Fritolay Makmur. Penelitian Dan Aplikasi Sistem Dan Teknik Industri, 11(1), 98-110. https://publikasi.mercubuana.ac.id/index.ph p/pasti/article/view/1358

Bell, J. L., \& Williams, J. C. (2018). Evaluation and Consolidation of the HEART Human Reliability Assessment Principles. In International Conference on Applied Human Factors and Ergonomics (pp. 3-12). Springer. https://doi.org/10.1007/978-3-31960645-3_1

Bin Jake, I. A. (2020). Analisis Probabilitas Human 
Error Berbasis Sop Pelayanan Operasional Pelabuhan Dengan Metode SHERPA dan HEART.Skripsi. Universitas Hasanuddin. http://repository.unhas.ac.id/id/eprint/1238/

Ghasemi, M., Nasleseraji, J., Hoseinabadi, S., \& Zare, M. (2013). Application of SHERPA to Identify and Prevent Human Errors in Control Units of Petrochemical Industry. International Journal of Occupational Safety and Ergonomics, 19(2), 203-209. https://doi.org/10.1080/10803548.2013.110 76979

Hughes, C. M. L., Baber, C., Bienkiewicz, M., Worthington, A., Hazell, A., \& Hermsdörfer, J. (2015). The application of SHERPA (Systematic Human Error Reduction and Prediction Approach) in the development of compensatory cognitive rehabilitation strategies for stroke patients with left and right brain damage. Ergonomics, 58(1), 7595.

https://doi.org/10.1080/00140139.2014.957 735

Kirwan, B. (2017). A Guide To Practical Human Reliability Assessment. CRC Press. https://books.google.co.id/books?id=jwZDD WAAQBAJ

Nurmianto, E. (2004). Ergonomi, konsep dasar dan aplikasinya. Surabaya: Guna Widya. https://onesearch.id/Record/IOS3755.JABA R000000000008819

Rahmania, T., Ginting, E., \& Kes, B. M. (2013). Analisa Human Error Dengan Metode Sherpa Dan Heart Pada Kecelakaan Kerja Di Pt "Xyz." Jurnal Teknik Industri USU, 2(1), 58-65.

https://jurnal.usu.ac.id/index.php/jti/article/vi $\mathrm{ew} / 3702$

Safitri, D. M., Astriaty, A. R., \& Rizani, N. C. (2015). Human Reliability Assessment dengan Metode Human Error Assessment and Reduction Technique pada Operator
Stasiun Shroud PT. X. Jurnal Rekayasa Sistem Industri, 4(1), 1-7. https://doi.org/10.26593/jrsi.v4i1.1388.1-7

Sanders, M. S., \& McCormick, E. J. (1993). Human Factors In Engineering and Design. McGraw-Hill Education. https://books.google.co.id/books?id=wJ0oA QAAMAAJ

Sembiring, N., Tambunan, M. M., \& Febriani, M. (2019). Human error analysis on production process of door products with SHERPA and HEART method. IOP Conference Series: Materials Science and Engineering, 505(1), 012025 . https://doi.org/10.1088/1757899X/505/1/012025

Torres, Y., Nadeau, S., \& Landau, K. (2021). Classification and Quantification of Human Error in Manufacturing: A Case Study in Complex Manual Assembly. In Applied Sciences (Vol. 11, Issue 2). https://doi.org/10.3390/app11020749

Utama, A. S. P., Tambunan, W., \& Fathimahhayati, L. D. (2020). Analisis Human Error pada Proses Produksi Keramik dengan Menggunakan Metode HEART dan SHERPA. Jurnal INTECH Teknik Industri Universitas Serang Raya, 6(1), 12-22. https://doi.org/10.30656/intech.v6i1.2114

Williams, J C. (2015). Heart-A Proposed Method for Achieving High Reliability in Process Operation by Means of Human Factors Engineering Technology. Safety and Reliability, 35(3), 5-25. https://doi.org/10.1080/09617353.2015.116 91046

Williams, Jeremy C, \& Bell, J. L. (2015). Consolidation of the Error Producing Conditions Used in the Human Error Assessment and Reduction Technique (Heart). Safety and Reliability, 35(3), 26-76. https://doi.org/10.1080/09617353.2015.116 91047 